and an amino-dicarboxylic acid; d-Lysyl-l-histidine, a dipeptide of two strongly basic amino-acids; 1-Asparagyl-1-tyrosine and d-glutamyl-l-tyrosine, two closely related dipeptides which, however, differ remarkably in their behaviour towards enzymes (see below); l-Tyrosyl-1-tyrosine, a dipeptide containing two phenolic groups; Glycyl-1-proline and d-alanyl1-proline, which occupy a distinctive position owing to the nature of the peptide linkage:-

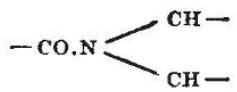

For comparison with these proline peptides another dipeptide in which the nitrogen of the peptide linkage is tertiary in character, namely, glycylsarcosine, has been prepared.

In the following table, the behaviour of these dipeptides is shown towards dipeptidase, towards aminopolypeptidase, and towards trypsin (that is, a mixture of proteinase and carboxypolypeptidase):

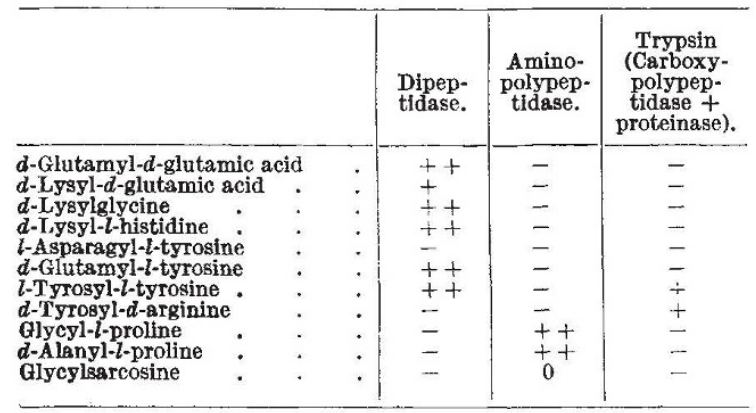

With glutamylglutamic acid the result is as one would expect ; this dipeptide, in spite of its strongly acidic character, is hydrolysed by dipeptidase after suitable buffering.

Lysylglutamic acid on the other hand is attacked only with difficulty by dipeptidase; lysylglycine is readily hydrolysed by this enzyme and the same is true of the strongly basic lysylhistidine. These examples show that the preponderance of acidic or of basic groups does not interfere with dipeptidase action, since the most strongly acidic and most strongly basic dipeptides are both attacked by the enzyme. Surprising differences of behaviour between closely related compounds are exemplified by asparagyl- and glutamyl-tyrosine, of which the first is resistant to all intestinal proteolytic enzymes whilst the second is readily hydrolysed by dipeptidase.

$l$-Tyrosyl- $l$-tyrosine presents an anomaly inasmuch as it is hydrolysed not only by dipeptidase but also by trypsin, whilst $d$-tyrosyl- $d$-arginine is actually not affected by dipeptidase but is hydrolysed by carboxypolypeptidase.

The behaviour of the proline peptides towards proteolytic enzymes is especially illuminating. Neither glycylproline nor alanylproline is attacked by dipeptidase whilst both are hydrolysed by aminopolypeptidase; here therefore we have two dipeptides for which dipeptidase is not the appropriate enzyme, and it becomes clear that the accepted definitions of dipeptidase and aminopolypeptidase are unsatisfactory. More important still is the conclusion which emerges from the experiments with the proline peptides that 'dipeptidase' can only attack a normal peptide linkage (.CONH.), whilst at least one constituent of 'aminopolypeptidase' can hydrolyse a peptide linkage in which the nitrogen atom is tertiary. This view is confirmed by the fact that glycylsarcosine is also resistant towards dipeptidase.

${ }^{1}$ Bergmann and Zervas, Biochem. Z., 203, 280; 1928.

2 Bergmann, Zervas and Lebrecht, Ber. deutsch. chem. fies., 64, 2315: 1931 .

${ }^{3}$ Bergmann and Ensslin, Z. physiol. Chem., 174, 76; 1928 : Berg mann and Stern, Liebigs Ann., 448, 20; 1926: Bergmann, Kann and Miekeley, Liebigs Ann., 449, 137; 1926: Bergmann and Miekeley, Liebigs Ann., 458, 40; 1927.

Bergmann and Delis, Liebigs Ann., 458, 76; 1927: Bergmann and Stather, Z. physiol. Chem., 152, 190; 1926.

${ }^{5}$ Bergmann and Köster, $Z$. physiol. Chem., 159, $179 ; 1926$ : Bergmann and Zervas, $Z$. physiol. Chem., 172, 277; 1927 : 173,$80 ; 1928$. - Zervas and Bergmann, Ber. deutsch. chem. Ges., 61, 1195; 1928 also Z. physiol. Chem. 201, 208; 1931: Kutscher, Ackermann, Flössner and Hopne-Seyler, Z. physiol. Chem., 199, 273 and $277 ; 1931$. ? Bergmann Stcrn and Witte, Liebigs Ann., 449, 277; 1926: Bergmann and Köster, Z. physiol. Chem., 167, 92; 1927 : Bergmann, Zervas and du Vigneaud, Ber deutsch. chem. Ges., 62, 1905 : 1929.

Zervas and du vigneaud, Ber deutsch. chem. Ges., 62, 1905 , 1929.932 : Bergmann, Zervas and Greenstein, Ber. deutsch. chem. Ges., 65, 1692 1932: Bergmann, Zervas, Schleich and lcinert, $Z$. physiol. Chem. 212, $72 ; 1932$.

\title{
West Regional Broadcasting Station in Great Britain
}

T will be remembered that a few years ago the British Broadcasting Corporation engineers ovolved what is known as the 'regional scheme' for covering Great Britain with an adequate broadcasting service providing alternative programmes of approximately the same strength. According to this scheme, each part of the country is catered for by a twin-wave transmitting station radiating both a national broadcasting programme and a regional programme specially arranged for the area under consideration. The fourth station of this type is now practically complete and experimental programme transmissions were commenced on April 24. The following details of this West Regional Station are taken from an article in World Radio of April 21

The station has been built near the Somerset coast at Washford Cross, two miles from Watchet and six miles east of Minehead. The site was chosen as being suitable for the provision of a good service to the important centres of population in the west of England and to South Wales in addition. The design of the station follows closely the general arrangement of the regional stations, and includes some of the modifications recently introduced at the Scottish Regional Station. Each of the two aerials employed is of the 'umbrella' type supported by an insulated lattice steel mast $500 \mathrm{ft}$. high. These two masts are illuminated at night by aircraft warning lights, which are fed through filter circuits to prevent the flow of high-frequency current in the lamp leads.

The whole of the electrical power required is generated locally by Diesel engine plant and sufficient fuel oil is stored for three months operation. For the various electrical supplies required, three of each type of motor-generator set are installed; one of these is in use on each transmitter, while one is spare. The national and regional transmitters are similar and of a standardised type of construction comprising five separate units. Modulation is carried out at an early stage following the drive oscillator. Two stages of high-power amplification follow, while the fifth unit contains the tuning and coupling circuits for the final power stage. In each stage it is possible to switch in a spare valve without interrupting the power supply. A studio for testing purposes is fitted up in the station buildings, although the programmes will normally emanate from the 
Cardiff studios. Entirely new studio premises at Bristol are now in course of erection.

The regional transmitter radiates on a wavelength of 309.9 metres, while the national programme is on $261 \cdot 6$ metres. The latter wave-length is already in use by the London national transmitter, and equipment is being installed by means of which the two sets may be exactly synchronised. The new service from this station will be introduced gradually in order to give listeners every opportunity of becoming accustomed to it, and of making any necessary modifications to their receivers so that they may take full advantage of the improved service.

\section{University and Educational Intelligence}

Cambridge.--Dr. M. Dixon has been appointed to the University lectureship in biochemistry, established in connexion with the scheme for the employment of the Rockefeller benefaction, and Dr. E. G. Holmes has been appointed to the University lectureship vacated by Dr. Dixon.

A. D. Thackeray, scholar of King's College, has been elected to the Sheepshanks exhibition.

LeEDs.-At the opening ceremony on April 25 of the Algernon Firth Pathological Institute, it was stated that the new building could not be brought fully into use owing to the lack of funds to equip the Museum which is essential to pathological teaching and research. Mr. Charles Ratcliffe Brotherton promptly offered $£ 1,000$, which will permit of the equipment of the Museum in a manner appropriate both to the fine architectural character of the room and to the importance of the work.

The West Yorkshire Coal Owners' Association has decided to renew its annual subscription of $£ 1,000$ to the Mining Department for a further period of seven years.

An offer by Mr. Bernard Scattergood to present to the University a transit theodolite for the Observatory has been gratefully accepted.

WALES.-The degree of D.Sc. has been awarded to Dr. Alan Edwin Bradfield, for research in the Department of Chemistry, to Miss Emily Dix, for research in the Department of Geology, and to $\mathrm{Mr}$. Frederick Daniel Smith, for research in the Department of Physics.

THE University of Bristol in its report for 1931-32 makes a special appeal for the endowment of open scholarships, pointing out that at no time in the last hundred years have so many citizens suffered so severely in taxation and diminution of income and consequent inability to afford to pay for university education for their sons and daughters. Notwithstanding the national financial stringency, the University succeeded in keeping its expenditure within its income and there was no falling off in the number of its students (day 973, evening 340). Extramural work continued to make satisfactory progress. Among new developments mentioned are the growth of confidence of farmers, fruit growers, market gardeners, willow growers and cider and canning industrialists in the value of the University's research and advisory work, the wide utilisation of the recently organised veterinary advisory service and the establishment of a special section to deal with poultry diseases. The Italian Government placed the services of Dr. Benvenuto Cellini at the disposal of the University for the session to encourage the revival of the study of Italian, which has been re-instated as a subject for the Intermediate Examination. Appended to the report is a list of 176 publications by members of the staff, chiefly those of the departments of science, pure and applied. It is announced that the Department of Zoology is to be re-organised and a professor appointed.

\section{Calendar of Nature Topics}

\section{Third 'Buchan Cold Spell'. The Ice Saints}

May 9-14. The period May 9-14, selected by Dr. A. Buchan as the third of his six annual cold spells, includes the three days of St. Mamertius, St. Pancras and St. Gervais, May 11-13, who are associated with May frosts in the folk-lore of a large part of Europe and are generally known as the 'Ice Saints'. This supposed cold spell has been attributed to a monsoon-like inflow of cold winds from the north, caused by the rapid warming-up of Central Europe in spring, and also to the obstruction of the sun's rays by a swarm of meteors. Another legend associates the cold spell with May 17-19, the latter being St. Dunstan's Day. There are frequently large fluctuations of temperature during May, and it is highly probable that a cold spell will occur some time during the month. During the present century, Buchan's period has frequently been marked by a drop of temperature in London, but from 1871 to 1900 it was generally warm, and on the whole there is no definite bias in favour of low temperatures at this time.

Breeding of Pearl Oysters coincident with Full Moon

Two additions to the records of the association of breeding with the state of the moon, were made by the Great Barrier Reef Expedition of 1928-29. The workers, stationed at Low Reef off the Coast of Queensland, found that the only pearl oyster which grew upon their island, the 'black-lip', had, like the larger 'gold-lip' which furnishes the greatest supply of mother-of-pearl, two breeding periods in the year, at the time of full-moon in May and in November. The second case, that of the madrepore coral Pocillopora, was described by Prof. T. A. Stephenson in Nature of April 29, p. 622.

\section{Eels - an Early Hypothesis}

"Their manner of breeding is very uncertaine and unknowne, but undoubtedly they are bred in the brackish or seawater: and at the first full Moone in May they begin to come into all great rivers, and out of great rivers into lesser rivers, and out of those lesser rivers into all small brookes, rils, and running waters, continually against the streame all the beginning of Sommer. . . I know that some holde opinion that they breed of the May deaw, for proofe whereof they say if you cut up two turfes of grass in a May morning and clap the grassie sides of those turfes together and so lay them in a river, you shall the next day find small young Eeles between the sayd turfes: and so you shall indeede. ... The reason is, at that time of the yeare that river being full of such young Eeles, they will creepe into every thing that is sweete and pleasant." (John Taverner, 1600.)

\section{Sun-Fish in British Waters}

May is the earliest month in which the sun-fish (Orthagoriscus mola) has been recorded in British waters, but the number of records rises throughout 